\title{
STUDENT'S MATHEMATICAL VALUE IN MATHEMATICS LEARNING USING NON-ROUTINE PROBLEM
}

\author{
Nurul Ain Safura, Nyimas Aisyah, Cecil Hiltrimartin, Indaryanti \\ Teacher Training and Education Faculty, Sriwijaya University \\ e-mail: safura0221@gmail.com
}

\begin{abstract}
This study aims to determine the ability of students in solving non-routine problems in learning mathematics in high school. The focus of the study is the ability of students in solving non-routine problems that include the value of objectism, value of control, value of mystery, value of progress, value of rationalism, and value of openness. The subject of this study was determined purposively, that was based on the diversity of answers. The selected subject was six students of class X SMA in Palembang. The data were collected using observation, test, and interview which were then analyzed descriptively. The results show that in general the ability of students in solving non-routine problems is dominated by the value of objectism, control, rationalism, and progress. The other two values which did not dominantly appear were mystery and openness.
\end{abstract}

Keywords: mathematical value, non-routine problem

\section{NILAI MATEMATIKA (MATHEMATICAL VALUE) SISWA PADA PEMBELAJARAN MATEMATIKA MENGGUNAKAN SOAL NON RUTIN}

\begin{abstract}
Abstrak: Penelitian ini bertujuan untuk mengetahui kemampuan siswa dalam menyelesaikan soal non rutin pada pembelajaran matematika di SMA. Fokus penelitian adalah kemampuan siswa dalam menyelesaikan soal non rutin yang meliputi nilai objektisme, nilai kontrol, nilai misteri, nilai kemajuan, nilai rasionalisme, dan nilai keterbukaan. Adapun subjek penelitian ini dipilih secara purposive, berdasarkan keberagaman jawaban. Subjek yang terpilih adalah enam orang siswa kelas X SMA di Palembang. Data dikumpulkan menggunakan observasi, tes, dan juga wawancara, yang kemudian di analisis secara deskriptif. Hasil penelitian menunjukkan bahwa secara umum kemampuan siswa dalam menyelesaikan soal non rutin masih didominasi pada nilai objektisme, nilai kontrol, nilai rasionalisme, dan nilai kemajuan. Dua nilai lain yang tidak dominan muncul adalah nilai misteri dan nilai keterbukaan.
\end{abstract}

\section{Kata Kunci: nilai matematika, soal non rutin}

\section{INTRODUCTION}

Human life will certainly never be separated from a problem. Of course as possible this problem must be overcome and not avoided. In this case, problem-solving abilities have a very important role. The government does not remain silent, the learning mathematics given to students at every level of education with the aim not only emphasizes learning outcomes but is also expected to be able to solve problems that include the ability to understand problems, design mathematical models, complete models and interpret solutions obtained (Depdiknas, 2006). From the learning objectives of mathematics above, it appears that the purpose of mathematics education in schools tends to focus on problemsolving abilities.
Polya (1973) defines problem-solving as an attempt to find a way out of a difficulty, achieving a goal that cannot be immediately achieved. According to Polya, the problemsolving process has four stages in solving it, namely (1) understanding the problem, (2) planning the solution, (3) implementing the plan, and (4) re-examining. When students are actively doing these four steps, students are optimally engaging themselves to determine strategies with related ideas in solving problems. In line with this, the importance of problem-solving is also reflected in one of the indicators of NCTM (2000) which states that learning programs from pre-childhood to grade XII must enable students to apply and adjust various strategies that are appropriate for solving problems. 
Problem-solving abilities are very important in mathematics, not only for those who will later study or study mathematics but also for those who apply it in other fields of study and in everyday life (Ruseffendi, 2006). Of course, the problems that will be faced are not all mathematical problems, but the problemsolving abilities studied in mathematics have a very central role in answering the daily problems. People who are skilled at solving problems will be able to race against their needs, become more productive workers, and understand complex issues related to the global community (Wardhani, Wiworo, Guntoro, \& Sasongko, 2010). This is why mathematics is still being studied even though it is already in college.

Problems can also be related to problemsolving, but not every problem can be called a problem. The problem will be a problem only if the question shows a challenge that cannot be solved by routine procedures that are known to the perpetrator (Wijayanti, 2012). A question is divided into two types, namely routine and non-routine questions. Routine questions are questions that can be solved by the procedures that have been studied. While non-routine questions are problems that have no fixed procedures to complete and require the use of one or more strategies to be solved (Yazgan, 2016). As for the problem to solve non-routine questions, further thinking is needed because the procedure is not as clear or not the same as the procedures that have been studied. In this new situation, there are clear objectives to be achieved, but the way to achieve them does not immediately appear in the minds of students (Aisyah, 2007).

Giving mathematics problem-solving questions will train and guide students to use the appropriate mathematical skills and concepts that they have learned to solve the problems they face (Utari, Arista, \& Fitri, 2016). By giving nonroutine questions, students will be accustomed to being placed in situations where they have to think mathematically and then be proficient in mathematical thinking through repetitive situations. From the description above it can be concluded that the problem-solving ability of non-routine math problems is the ability of students to solve mathematical problems in the form of questions, but the problem makes students do not directly know how to solve it, need further thinking because the procedure is not as clear as the procedures that have been studied.

The fact that happened, mathematics education which was considered important, had not shown satisfying conditions for the world of Indonesian education (Hasratuddin, 2008). The core problem in mathematics education in Indonesia is the low quality of education indicated by the low student achievement both on a national and international scale (Zulkardi, 2005). The achievements of Indonesian children in the field of mathematics are always slumped every time reports are issued by PISA and TIMSS.

Based on the PISA study report, in 2000 Indonesia was in the 39th position out of 41 countries, in 2003 it was 38 th out of 40 countries, in 2006 it was 50th out of 57 countries, in 2009 it was 61th out of 65 countries, in 2012 it was 64th out of 65 the country and 2015 placed Indonesia in 63rd position out of 70 countries (OECD, 2016). Based on data from the 2011 TIMSS results for the category of junior high school Indonesia ranked 38 of 42 countries (IEA, 2013), in 2015 for the SD category, Indonesia was ranked 45 of 50 countries (IEA, 2015). As for the OECD (2013), almost $80 \%$ of Indonesian students are at level one and only $25 \%$ of students who reach level two and above. Analysis of the results of TIMSS 2015 shows that Indonesian students tend to master routine, simple computational questions, and measure knowledge of daily contextual facts (Tim Puspendik, 2016). It's really sad that this can happen because this data shows that the achievement of Indonesian students in the field of mathematics is so low in the international world. In fact, the purpose of mathematics learning in accordance with the 2013 Curriculum is that students are required to be able and skilled in solving problems and linking mathematical concepts in daily life (Kemendikbud, 2013).

As is well known, PISA contains material about routine and non-routine questions that are used to measure the level of mathematical problem-solving abilities with $25 \%$ of the material, number of numbers, algebra, and statistics. It is very regrettable that the material for international standard examinations, in this case, is that PISA is tested not all of them are mastered by students so that Indonesian students cannot answer them because the test material 
provided is non-routine questions (Kesumawati, 2009). Likewise, with the TIMSS study, Noer (2009) said from the results of the TIMSS study revealed that Indonesian students were weak in solving non-routine questions related to proof and problem solving that required mathematical reasoning, finding generalizations and finding relationships between data or facts which is given. This means that mathematics learning, especially non-routine questions, needs to be designed so that it can trigger students to be able to analyze and use mathematics in their daily lives.

The lack of skilled students in solving non-routine questions, one of them is because students are rarely taught non-routine questions themselves (Doorman et al, 2007). During this time taught mostly in school is closed mathematical problems and in solving these closed mathematical problems, the procedure used is almost standard (Suandito, 2009). Therefore, the use of non-routine questions in mathematics learning must be more often applied to students in Indonesia in the hope that students have the ability to solve problems that are supposed to be owned by students.

Non-routine questions are questions whose resolution requires a complex strategy. Therefore, to solve non-routine questions must involve cognitive, effective, and psychomotor aspects. The most dominant affective aspect, in this case, is the value of mathematics (mathematical value) applied by students in solving non-routine problems (Aisyah, 2007). Mathematical value is a person's tendency towards a more meaningful understanding of mathematics. Furthermore, Seah \& Bishop (2000) identified three pairs of interrelated mathematical values namely, rationalism-objectism, control-progress, and openness-mystery.

a. Rationalism - Objectism

Value of rationalism shows the ability to use deductive reasoning involving ideas that depend on logic, hypotheses, and arguments, while the value of objectism shows the ability to use symbols that can conclude mathematics that has abstract language (Bishop, 1999; Seah \& Bishop, 2000).

b. Control - Progress

Control values show the ability to use rules and the ability to apply ideas to situations of solving everyday life problems, while progress values indicate the ability to generalize about ideas or procedures for solving mathematical problems to be used in other problem situations, showing how to use non-routine settlement strategies, making generalizations based on specific examples and generating student motivation with a history of mathematical development (Bishop, 2000).

c. Openness - Mystery

value of openness shows that the ability to discuss and analyze mathematical theorems, ideas, and arguments, while the value of mystery shows that mathematics has relationships, patterns, and surprises in it.

The emergence of mathematical values will make learning more memorable, interesting, meaningful and useful to students. This is because the value of mathematics will arouse a sense of beauty towards mathematics, generate an understanding of mathematical interests in life and can help students master the power of mathematics better (NCTM, 1989).

Research on mathematical values has been carried out by Ali (2005). This study found three perspectives of teachers' thinking on the meaning of mathematical values, namely the value of mathematics as pure value, the value of mathematics as an intrinsic value, and the value of mathematics as a useful value in life. Another study was conducted by Seah \& Bishop (2000), Dollah (2005), and Resi (2012) who found the application of mathematical values by teachers in teaching mathematics in class. The last is the research of Indaryanti, Aisyah, \& Erfiani (2017) showing that students apply mathematical values when solving mathematical problems with modeling. The mathematics values applied by this student are the value of objectism, the value of control, the value of mystery, the value of rationalism, and the value of progress. However, in these studies, the questions used were only limited to routine questions. Research that focuses on non-routine problem solving has not been discussed in depth. Therefore, this study will examine in depth the ability of students to solve non-routine problems in learning mathematics in high school.

\section{METHODS}

This research is a descriptive study with a qualitative approach. The focus of this study 
is the ability of students to solve non-routine questions on mathematics learning in state high schools in Palembang. Ability is ability; proficiency; strength (Kamus Pusat Bahasa, 2008). As for solving non-routine questions, further thinking is needed because the procedure is not as clear or not the same as the procedures that have been studied, in the new situation, there are clear objectives to be achieved, but the way to achieve them does not immediately appear in the minds of students (Aisyah, 2007). The research subjects were determined purposively, based on the diversity of answers. The subjects selected were class X public high school students in Palembang academic year 2017-2018 as many as six people. The six students were chosen, because they have a variety of abilities in solving non-routine questions seen from the aspect of mathematics values, getting recommendations from the teacher and being willing to be involved in the research.

The ability of students to solve non-routine questions includes the value of objectism, the value of control, the value of mystery, the value of progress, the value of rationalism, the value of openness with indicators as follows.

1. Value of objectism (the ability of students to translate everyday problems in mathematical sentences that are simpler by using symbols)

2. Value of control (the ability of students to use rules or formulas in solving mathematical problems)

3. Value of mystery (the ability of students to solve problems related to beauty/uniqueness in mathematics)

4. Value of rationalism (the ability of students to investigate the truth of the steps in solving mathematical problems or students using mathematical manipulation in completing tasks)
5. Value of progress (the ability of students to solve mathematical problems in other problem situations or students make conclusions about something or procedure for solving mathematical problems)

6. Value of openness (the ability of students to use their own way of solving problems)

In the implementation phase, the researcher first guides and observes 34 students through their answers on LKPD (Student Worksheet). LKPD which contains real non-routine problems with the material of the Three Variable Equation System (SPLTV) is given for two meetings, with the aim of guiding students to be able to solve nonroutine problems. Then a written test was given in the form of three non-routine questions about SPLTV material to class X high school students in Palembang. In working on the test questions students were given a time limit of 90 minutes. The non-routine questions used by researchers as test questions are questions that have been developed in the research of Indaryanti, Aisyah, Astuti, \& Winarni (2017). Of the three questions tested to students, not all indicators can appear on each question, because the criteria given are not supported for the indicator, this can be seen in Table 1 below.

In this study, the subject's ability to solve non-routine questions is categorized into three categories, including high, medium, and low categories categorized by looking at the number of mathematical values that appear on the subject through observation, analysis of the results of written tests, and interviews. From the results of the written test analysis, the researcher obtained an overview of the abilities of 34 students. Then nine students were chosen as prospective subjects who had a variety of answers. Nine students were then discussed with the teacher. Then, the teacher recommended six out of nine

Table 1. The emergence of Indicators of Ability to Complete 3 Non-Regular Questions in Problem Test

\begin{tabular}{|c|c|c|c|c|c|c|c|}
\hline \multirow{2}{*}{$\begin{array}{c}\text { Problem } \\
\text { no. }\end{array}$} & \multicolumn{6}{|c|}{ Students' Mathematical Values Completing Non-Routine Questions } & \multirow{2}{*}{$\begin{array}{c}\text { Total } \\
\checkmark\end{array}$} \\
\hline & Objectism & Controls & Mysteries & Rationalism & Progress & Openness & \\
\hline 1. & $\checkmark$ & $\checkmark$ & - & $\checkmark$ & $\checkmark$ & $\checkmark$ & 5 \\
\hline 2. & - & $\checkmark$ & - & $\checkmark$ & $\checkmark$ & $\checkmark$ & 4 \\
\hline 3. & - & - & $\checkmark$ & - & $\checkmark$ & $\checkmark$ & 3 \\
\hline \multicolumn{7}{|c|}{ Amount } & 12 \\
\hline
\end{tabular}


students as prospective subjects. Researchers asked the willingness of six prospective subjects to be examined further, namely interviewed and they all agreed. So from this process, six people were chosen as subjects in this study (Dollah, 2007). The six people are students who have heterogeneous abilities and motivation. After the research subject was determined, the researcher began to conduct interviews. The interviews used in the study were semi-structured interviews using interview guides derived from the topic development and were presented with more flexibility, the purpose of which was to deepen information about students' ability to solve nonroutine questions that had been obtained from test data. As for this study, interviews were conducted once for each subject.

\section{RESULTS AND DISCUSSION}

\section{The results of the study}

The research process from the planning study includes the determination and selection of research topics of school as a place of research, which in turn is carried out through three stages of the research, which is under preparation, data collection, and data analysis. In the data analysis stage, an analysis of the subject's ability to solve non-routine questions is based on the appearance of the indicator on the subject's answer sheet during a written test and analyzing it also based on the results of the interview. Table 2 below is the result of the analysis of capability data based on the subject's written test.

Table 2 above shows that the information from three written test questions given to students, it turns out that indicators 1, 2, and 4 are the dominant indicators that appear in students. For indicator 5, it turns out there are still students whose abilities do not appear, while indicators 3 and 6 are non-dominant indicators that appear in students.

The value obtained by the subject is then classified according to the categories that have been made by the researcher based on the modification of Aisyah (2016) and Arikunto (2015). As in table 3 below:

Table 3. Classification of Categories of Ability to Complete Non-Routine Questions

$\begin{array}{ccc}\text { No. } & \begin{array}{c}\text { The number of indicators } \\ \text { that appear (from } 3 \text { questions) }\end{array} & \begin{array}{c}\text { Ability } \\ \text { Category }\end{array} \\ 1 . & 11-12 & \text { High } \\ 2 . & 9-10 & \text { Medium } \\ 3 . & 0-8 & \text { Low }\end{array}$

The selected subjects include high-ability subjects (Subject AT and NA), two students with moderate ability (JP and SW subjects) and two other low-ability mathematicians (MT and WI subjects). Complete results of data analysis based on test results are also supported by interviews presented below:

Value of objectism appears in the answers of all subjects in problem number one. As the answer of WI subject in Figure 1 translates the existing problems by making these problems into more mathematical sentences simple, namely by using the symbol ${ }^{x}$ for Dika, ${ }^{y}$ for father, and ${ }^{z}$ for grandfather.

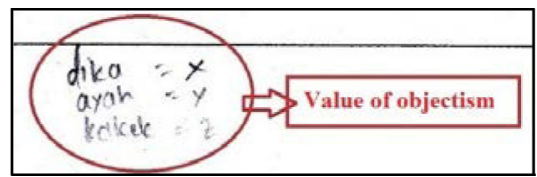

Figure 1. The answer to question No. 1 of the WI subject to the value of objectism

Table 2. Subject Ability to Resolve Non-Routine Questions

\begin{tabular}{|c|c|c|c|c|c|c|c|c|c|c|c|c|c|c|c|c|c|c|c|}
\hline \multirow{3}{*}{ Name of } & \multicolumn{18}{|c|}{ Indicator / Problem No } & \multirow{3}{*}{$\underset{\checkmark}{\text { Quantity }}$} \\
\hline & \multicolumn{3}{|c|}{1} & \multicolumn{3}{|c|}{2} & \multicolumn{3}{|c|}{3} & \multicolumn{3}{|c|}{4} & \multicolumn{3}{|c|}{5} & \multicolumn{3}{|c|}{6} & \\
\hline & 1 & 2 & 3 & 1 & 2 & 3 & 1 & 2 & 3 & 1 & 2 & 3 & 1 & 2 & 3 & 1 & 2 & 3 & \\
\hline SW & $\checkmark$ & - & - & $\checkmark$ & $\checkmark$ & - & - & - & $\checkmark$ & $\checkmark$ & $\checkmark$ & - & $\checkmark$ & $\checkmark$ & $\checkmark$ & $\checkmark$ & $\checkmark$ & $\checkmark$ & 12 \\
\hline NA & $\checkmark$ & - & - & $\checkmark$ & $\checkmark$ & - & - & - & $\checkmark$ & $\checkmark$ & $\checkmark$ & - & $\checkmark$ & $\checkmark$ & $\checkmark$ & $\checkmark$ & $\mathrm{x}$ & $\checkmark$ & 11 \\
\hline AT & $\checkmark$ & - & - & $\checkmark$ & $\checkmark$ & - & - & - & $\mathrm{x}$ & $\checkmark$ & $\checkmark$ & - & $\checkmark$ & $\checkmark$ & $\checkmark$ & $\checkmark$ & $\checkmark$ & $\mathrm{x}$ & 10 \\
\hline JP & $\checkmark$ & - & - & $\checkmark$ & $\checkmark$ & - & - & - & $\mathrm{x}$ & $\checkmark$ & $\checkmark$ & - & $\checkmark$ & $\checkmark$ & $\checkmark$ & $\checkmark$ & $\mathrm{x}$ & $\mathrm{x}$ & 9 \\
\hline WI & $\checkmark$ & - & - & $\checkmark$ & $\checkmark$ & - & - & - & $\mathrm{x}$ & $\checkmark$ & $\checkmark$ & - & $\checkmark$ & $\mathrm{x}$ & $\checkmark$ & $\mathrm{x}$ & $\mathrm{x}$ & $\mathrm{x}$ & 7 \\
\hline MT & $\checkmark$ & - & - & $\checkmark$ & $\checkmark$ & - & - & - & $\mathrm{x}$ & $\checkmark$ & $\checkmark$ & - & $\checkmark$ & $\mathrm{x}$ & $\mathrm{x}$ & $\mathrm{x}$ & $\mathrm{x}$ & $\mathrm{x}$ & 6 \\
\hline $\begin{array}{ll}\text { Description } \\
\checkmark & : \text { Mathema } \\
\mathrm{x} & : \text { Indicator } \\
- & : \text { Problem }\end{array}$ & $\begin{array}{l}\text { nath } \\
\text { sup! }\end{array}$ & $\begin{array}{l}\text { ati } \\
\text { tin }\end{array}$ & $\begin{array}{l}\text { va } \\
\text { br }\end{array}$ & $\begin{array}{l}\mathrm{s} d \mathrm{p} \\
\mathrm{up}\end{array}$ & $\begin{array}{r}\text { ears } \\
\text { not } \\
\text { dica }\end{array}$ & pear & & & & & & & & & & & & & \\
\hline
\end{tabular}


As according to WI, when asked what was the first step he chose, the WI subject said that he first symbolized the known data with the aim of making the data more detailed. This means, even though the WI subject is a subject with a low ability category, the value of objectism can still appear to him.

Control values that use subject rules or formulas also appear in all subjects. This value can be seen in the subject's answer to questions number 1 and 2. For problem number 1, the control value can be seen in the answer of subject SW. WI subjects use the concept of elimination as shown in Figure 2. Subjects made several eliminations on existing equations and processed the data until the value of was obtained $b=\frac{1}{s}$.

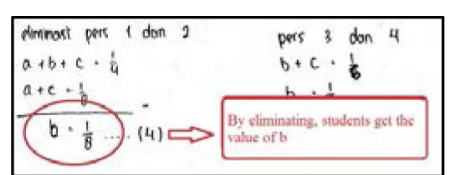

Figure 2. Answers to problem no.1 subject SW for control values

When conducting interviews, information was obtained that the subject is able to and understand the meaning of the elimination done. As for problem number 2 , the control value can be seen in the answer to the JP subject as shown in figure 3 . JP subjects do the elimination and substitution to solve the given problem.

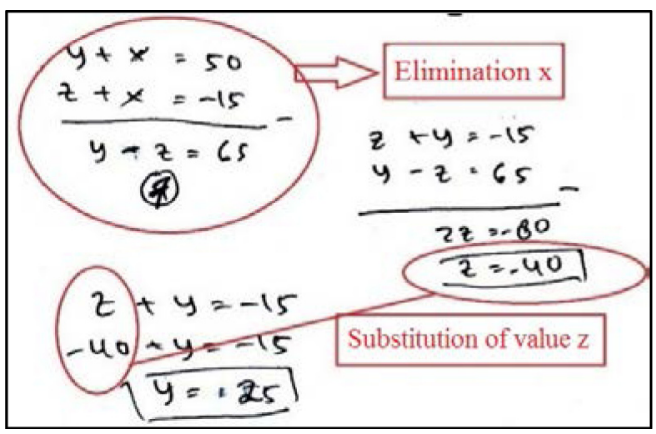

Figure 3. Question No. 2 of the JP subject for the control value

When interviewing the subject stated that in solving the problems in problem number 2 , the JP subject used elimination and substitution he had learned in junior high school and also in high school. According to him, this step is chosen by the subject because elimination and substitution he considers being the most appropriate way to find the correct answer to problem number 2 . This means that the control value does appear on the JP subject.

The mystery value of the subject appears in terms of solving problems related to beauty or uniqueness in mathematics in problem number 3 which can be solved by various strategies as shown in Figure 4. In this study, the value of mystery only appears in subjects with high ability categories only, namely on the subject SW and subject NA. Whereas in subjects with the medium ability and low ability categories, the value of this mystery does not appear. For subjects with low ability and medium ability, they stated that they had tried to guess and some were counting, but they still did not find the right answer. There are also subjects who have given new symbols for the empty circle in question, then use the steps as the SPLTV material, but he also cannot find the right answer.

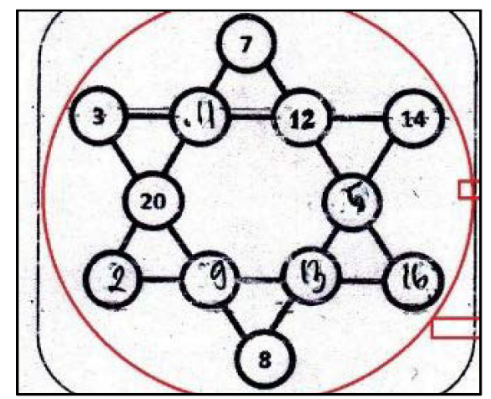

Figure 4. Question number 3 subject $\mathrm{SW}$ for mystery value

Although when interviewing the subject SW stated that in solving this given problem he used a guessing strategy to find the answer, it turns out that as in Figure 4 it can be seen that the SW subject is able to find the correct answer, he finds the same amount for each line, which is 40 .

The value of rationalism appears in all subjects, both in number 1 and in problem number 2. In the JP subject, the value of rationalism appears in questions number 1 and 2 when the subject investigates the correct steps in completing the problem. The following in Figure 5 is the answer to the JP subject to problem number 1 which proves the results he has obtained. 


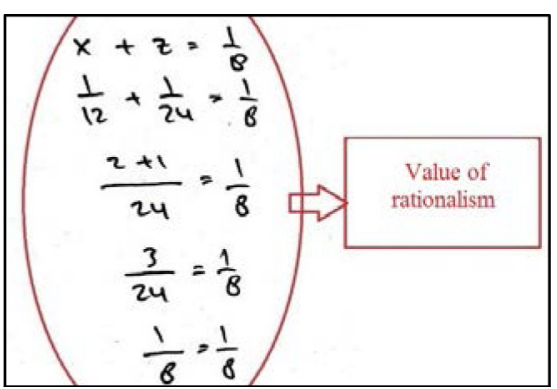

Figure 5. Question answer no.1 JP subject for the value of rationalism

When the researcher asked what was the purpose of the step chosen by the JP subject as shown in Figure 5, the JP subject stated that this was done to prove whether the answer he obtained was true or not. As for the MT subject, the value of rationalism arises when he manipulates the questions number 1 and 2. The MT subject makes what data is known and asked about the problem as in Figure 6 below Question

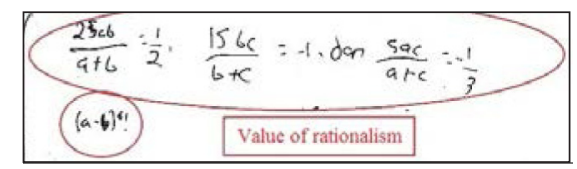

Figure 6. Question answer no.2 MT subject for the value of rationalism

The statement of the MT subject to the following researcher supports the emergence of the value of rationalism in problem number 2 : "This is made known as $a, b, c$, and is constantly being asked (in the matter). Asked value of $(a-b)^{c}$. The subject states that he first made the data known and the question asked. The

Value of progress appears in all subjects. In the questions, number 1, 2, and 3, the subject draws conclusions about an existing problemsolving procedure or procedure Figure 7 shows the emergence of the value of progress on the subject NA. The subject NA makes a conclusion to the problem in problem number 1 .

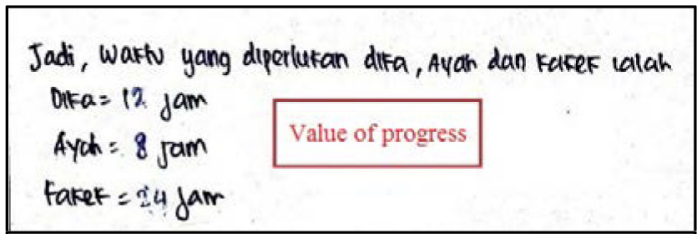

Figure 7. The answer to problem no.1 subject NA for the value of progress
When interviewed between the researcher and the subject NA, according to the subject NA the conclusion for the result was that Dika can finish the job for 12 hours, the father can complete the work for eight hours and grandfather can complete the job for 24 hours. The results of the interview stating that he has obtained the time needed by Dika, father and grandfather as in Figure 7 also supports the emergence of the value of the subject's progress NA, as for the appearance the value of progress on Question 2, can be seen on the subject answers AT like those in figure 8. Initially, the subject of important steps to resolve issues related to the problem turned this value, then eventually the subject of AT makes a final conclusion that is $(0)^{\frac{a-1}{40}}$ to solve the problem in problem number 2 .

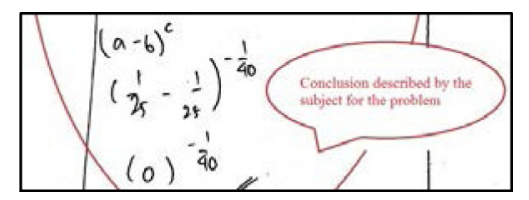

Figure 8. Question answer No. 2 subject AT for the value of progress

Although in the interview between the subject of AT and the researcher, the subject of AT stated that he did not know exactly what the value of $(O)^{-\frac{1}{40}}$, but in fact he has made a conclusion that the final answer was $(0)^{\frac{a-1}{40}}$ thus the value of the progress still remains on the subject of aT. As for problem number 3 , the value of progress can be seen in the answer to the subject WI in figure 9. When the researcher conducted an interview with the WI subject, the WI subject stated that he had tried to answer in a guessing way but the results seemed inappropriate. However, even though the results given by the WI subject are not correct, where there is each line that amounts to $30,33,46$, also 48 , so the number of numbers on one line that he answers do not give the same amount. Whereas in question number 3 , the subject should be able to find the numbers so that the number of each line is the same, but still it must be admitted that the WI subject has made conclusions as in Figure 9 below: 


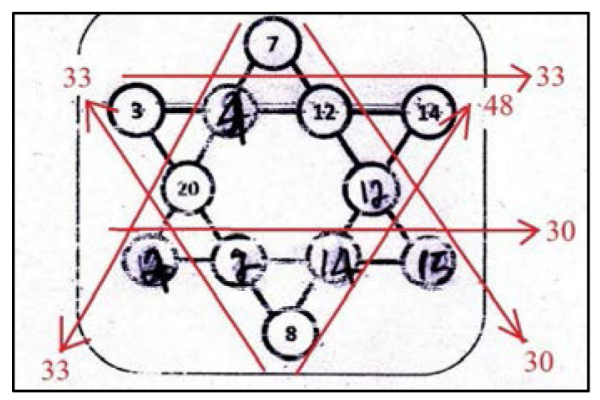

Figure 9. Question number 3 WI subject to the value of progress

Openness value is subject only based on the results of the analysis of the subject's answers without interviews, then the value of openness only appears in the SW subject that is the answers to questions number 1, 2, and 3, the subject NA on the answers to questions number 1 and 3, subject AT on the answer the questions number 1 and 2, and JP on the answer to question number 1. But after the interview with the subject of SW and subject AT of their answers to problem number 2, the two subjects were unable to explain the value from. So that the openness value does not appear on the answer of the subject SW and subject AT in matter number 2. The appearance of the openness value for the subject of AT is shown in Figure 10:

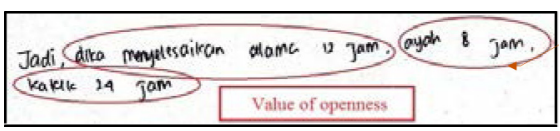

\section{Figure 10. Question 1 of the subject AT for the openness value}

Subject AT states that the final answer gets that Dika can finish for 12 hours, dad can finish for 8 hours and grandfather can finish for 24 hours. This also supports the emergence of the value of progress on the subject AT.

The openness value also appears in the answer to question number 3 as in figure 11 which is the answer to the subject NA. With a trial and error step, NA subjects were able to find answers correctly. Each line has the same number of 40 , as shown in this figure:

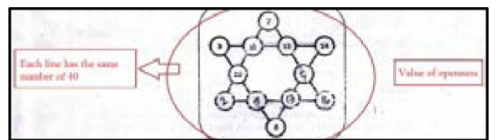

Figure 11. Question No. 3 subject NA for the value of openness
When interviewed, subject NA stated that he used trial and error several times to find the right answer, only then did he succeed in getting the right answer.

\section{Discussion}

In mathematics learning, students should not only obtain knowledge through subjects but indirectly be educated through the values that exist in learning (Othman, Zakaria, \& Iksan, 2014). Bishop (2008) identifies three interconnected mathematical values, namely, rationalism-objectism, control-progress, and mystery-openness. In this study, the three related values are further translated into six values, each of which remains in touch, including the value of objectism, the value of control, the value of mystery, the value of rationalism, the value of progress, and the value of openness.

These six values have their own descriptors, including the value objectism descriptor that is students translate everyday problems in the form of simpler mathematical sentences using symbols. Descriptors value student control, which uses rules or formulas in solving mathematical problems. Descriptors are mystery values that our students solve problems related to beauty/uniqueness in mathematics. Descriptors value rationalism, namely students investigate the truth of the steps in solving mathematical problems or using mathematical manipulation in completing tasks. Descriptors of progress values, namely students making conclusions about an idea or procedure for solving mathematical problems. Finally, the descriptor is the value of openness, i.e. students solve problems using their own methods.

Based on the results of the analysis of test and interview data, indicators for students' ability to solve non-routine problems were the dominant subjects in this study, in fact, only four of the six indicators were expected, including the value of objectism, value of control, value of rationalism, and value of progress. While the value of mystery and the value of openness becomes a little value appears. The value of objectism is the value that appears in all subjects. The subject is able to translate the problem in the form of a story problem to a more simple mathematical sentence form using symbolsandorand and say that this is done to facilitate the subject in solving the problem. This value is due to 
students accustomed to being taught by the teacher to translate problems in story problems with symbols, in teaching the teacher indirectly implements this particular ability to his students as described Dollah (2005), generally the application of objectism values implicitly implicit in classroom teaching, students describe the meaning of the problems they encounter by representing the problem back into symbols or diagrams to help in understanding the problem and then applying problem-solving to make it easier. This is what makes that in all subject the objectism values appear.

The values control also appear in all subjects. The value of this control is caused by the experience of the subject to solve previous problems. Subjects have studied and used substitution and elimination rules that have been learned during junior and senior high school on SPLDV material. Now, the subject is applying it to non-routine questions that can be solved with SPLTV. Sternberg \& Sternberg (2012) stated that the use of previous experiences is an analogy approach in problem-solving. As well as Mairing (2017) said a good problem solver has a problemsolving plan that has been resolved before useful in developing a plan to solve the problem at hand. Subjects are able to use their knowledge to solve existing mathematical problems until finally, the control value can emerge, this is in agreement with Hudojo (2005) which explains that students who have knowledge related to other knowledge, the students are better able in solving problems.

The value of rationalism is also a dominant value that emerged in this study. Dollah (2005) states "The dominant value of mathematical value is the value of rationalism and objectism" in other words, the dominant value involved in mathematical value is the value of rationalism and the value of objectism. Subjects are able to prove for questions number 1 and 2, some are doing mathematical manipulation correctly. The emergence of the value of rationalism is also caused by the modeling learning chosen by the researcher, because based on the results of Efriani, Aisyah, \& Indaryanti, (2017) research on the use of worksheets based on control values and rationalism values in learning mathematical modeling shows good categorical results to increase the value of student rationalism. As before, researchers use LKPD by using a modeling approach to lead students so that their rationalism values can emerge.

For the value of mystery that is only controlled by subjects with high ability category, it actually only requires the ability of the subject to first understand the problem, find the best way then, find the solution. Two subjects who solved exactly the number 3 problem, where this question supports the emergence of the value of mystery by trial and error. Basically this problem can indeed be solved by guessing or trial and error, but of course further thought is needed to solve the problems related to the value of this mystery, because the problem given is a new situation that has never been met before (Retnowati, Fathoni, \& Chen, 2018).

The things that make the value of the mystery of the majority of the subject does not appear as well Yeo \& Joseph (2009) explains that the problem of non-routine, namely: "It had to be reasonably complex but approachable and requiring no specific high-level mathematics." In other words, Non-routine problems are complex problems that are logical but can be solved and to solve them does not require a certain high level of mathematics. Plus teachers rarely provide non-routine types of questions such as questions given by researchers, in line with the opinion of Suandito (2009) that teachers still rely a lot on textbooks including the selection of test material for student evaluation even though mathematics textbooks contain little non-routine questions.

The value of progress is also a dominant value. The subject that does not appear in the progress value is believed to be because the subject has difficulty in understanding the concept of operations in the given form of algebraic fractions. As with Widiyanti, Zubaidah, \& Yani, (2015) regarding the analysis of students 'difficulties in solving algebraic fraction material problems explained that students' difficulties occur because students do not understand the concept of operations in algebraic forms. Weaknesses and difficulties of students in answering problem-solving problems are caused by low mastery of mathematics, such as mathematical concepts (Hartati, Abdullah, \& Haji, 2017). In fact, by solving mathematical problems, making mathematics does not lose its meaning, because a concept or principle will be meaningful if it can be applied in problemsolving (Sunarto, Budayasa, \& Juniati, 2017). It 
is an apprehensive situation, because the subject whose progress does not appear means losing the meaning of mathematics itself.

Based on the results of the study it was also found that the value of openness became the least value that appeared. Students have difficulty pouring their own thoughts or ideas to solve problems. The causes of this matter are explained in the research Mujulifah, Sugiatno, \& Hamdani (2015) which explains that there are many students who are not fluent in composing their arguments, due to the lack of trained students in communicating their understanding, ideas or ideas, students are tend to imitate example because they did not possess sufficient knowledge base to try solving problem using their own arguments (Retnowati, Ayres, \& Sweller, 2018). Although teachers tend to provide opportunities for students to try to answer themselves, but unfortunately often teachers limit the strategies that may be used by students, plus the ability of students to be less developed because students are only used to pay attention to examples then record the completion shown by the teacher (Juanti, Santoso, \& Hiltrimartin, 2016, 2005; Aisyah, 2016). A short settlement without understanding deeper concepts that result in students having difficulty in assembling arguments to show their understanding, as well as in terms of presenting the results of problem solving.

Not the emergence of value this is also due to the understanding of subjects in this study not related to other knowledge about the meaning of SPLTV, agreeing with Mairing (2017) that inability is due to students' understanding of SPLTV is limited to procedural knowledge without meaning. These conditions make the entire process carried out by students in solving the mathematical problems given from the beginning and end do not give satisfactory results.

\section{CONCLUSION}

Based on the results of the study, it can be concluded that there are two subjects who are able to perform all indicators, namely indicators translating problems using symbols, using rules or formulas, solving problems related to beauty/ uniqueness in mathematics, investigating the correctness of steps steps or using mathematical manipulation, drawing conclusions on ideas or procedures for solving mathematical problems, and solving problems using their own methods. The other two subjects are able to translate problems using symbols, using rules or formulas, investigating the correctness of steps or using mathematical manipulation and drawing conclusions about ideas or procedures for solving mathematical problems. As for the ability to solve problems using their own methods, only appears a little. While the ability to solve problems related to beauty/uniqueness in mathematics does not appear at all. The last, two subjects are only able to translate problems using symbols, using rules or formulas, and investigating the correctness of steps or using mathematical manipulation. The ability to draw conclusions on ideas or procedures for solving mathematical problems appears only a little. While the ability to solve problems related to beauty/uniqueness in mathematics and also the ability to solve problems using their own methods does not appear at all.

In general, the ability of students to solve non-routine questions is still dominated by the ability to translate problems using symbols that are part of the value of objectism, using rules or formulas that are part of the value of control, investigating the correctness of steps or using mathematical manipulation which is part of the value of rationalism and draw conclusions about ideas or procedures for solving mathematical problems that are part of the value of progress. While the other two abilities are not dominant in non-routine problem solving, namely the ability to solve problems related to beauty/uniqueness in mathematics and the ability to solve problems using their own methods. These two abilities in a row are part of the value of mystery and the value of openness.

\section{THE ACKNOWLEDGMENTS}

Authors would like to thank FKIP Sriwijaya University for providing the Sriwijaya University FKIP PNPB grant for the 2017 budget year so that this research can be completed.

\section{REFERENCES}

Aini, R.N, \& Siswono, T.Y.E. (2014). Analisis pemahaman siswa SMP dalam menyelesaikan masalah aljabar pada PISA. MATHEdunesa JIPM. 3(2):158-164. Retrieved from http://jurnalmahasiswa. 
unesa.ac.id/index.php/mathedunesa/ article/view/8718/8768).

Aisyah, N. (2007). Pengembangan pembelajaran matematika SD. Jakarta: Depdiknas.

Aisyah. N. (2016). Penerapan nilai oleh guru dalam pengajaran matematik di sekolah menengah pertama Palembang. Disertasi. Malaysia: UPSI.

Ali, W.Z.A., Husain, S.K.S., Ismail, H., Hamzah, R., Ismail, M.R., Konting, M., Tarmizi, \& R.A. (2005). Kefahaman guru tentang nilai matematik. Jurnal Teknologi. 43(E), 45-62. doi: 10.11113/jt.v43.793.

Arikunto, S. (2015). Dasar-dasar evaluasi pendidikan. Jakarta: Bumi Aksara.

Bishop, A.J. (1999). Mathematics teaching and value education - An intersection in need of research. ZDM Mathematics Education. 31(1):1-4. 10.1007/978-0-387-096735_16.

Bishop, A.J. (2000, 3 November). Overcoming obstacles to the democratization of mathematics education. Regular lecture presented at the Ninth International Congress on Mathematics Education, Makuhari, Japan. Retrieved from http:// www.education. monash.edu.au/ projects/ vamp/mav98.html.

Bishop, A.J. (2008). Teacher's mathematical values for developing mathematical thinking in classroom: theory, research, and policy. The Mathematics Educator. 11 (1/2), 79-88. Retrieved from https://www.researchgate.net/ publication/251676085_Teachers' Mathematical_Values_for_Developing _ Mathematical_Thinking_in_Classrooms Theory_Research_and_Policy.

Depdiknas RI Nomor 22 Tahun 2006 tentang Standar Isi Kurikulum

Dollah, M.U. (2005). Cabaran penerapan nilai matematik dalam pengajaran matematika sekolah menengah (challenges of inclucating mathematical values in teaching mathematics at secondary school). Jurnal Pendidikan Sains \& Matematik Malaysia, 2(1): 38-50. Retrieved from https://ejournal.upsi.edu. my/article/2016AR000884.

Doorman, M., Drijvers, P., Dekker, T., HeuvelPanhuizen, M., de Lange, J. \& Wijers, M. (2007). Problem solving as a challenge for mathematics education in The Netherlands. ZDM Mathematics Education. 39(56):405-418. doi: 10.1007/s11858-0070043-2

Efriani, A., Aisyah, N., \& Indaryanti. (2017). Penggunaan lembar kerja siswa berbasis nilai kontrol dan nilai rasionalisme pada pembelajaran pemodelan matematika. IDEAL MATHEDU. 4(6): 379-388. Retrieved from http://idealmathedu. p4tkmatematika.org/ articles/V4-No6AEfriani.pdf.

Hartati, S., Abdullah, I., \& Haji, S. (2017). Pengaruh kemampuan pemahaman konsep, kemampuan komunikasi dan koneksi terhadap kemampuan pemecahan masalah. MUST. 2(1): 43-72. doi: $10.22342 / \mathrm{jpm} .11 .2 .3354$.

Hasratuddin.(2008). Permasalahan pembelajaran matematika sekolah dan alternatif pemecahannya. Pythagoras. 4(1):67-73. doi: 10.21831/pg.v4i1.688

Hudojo, H. (2005). Pengembangan Kurikulum dan Pembelajaran Matematika. Malang: UM Press.

IEA. (2013). TIMSS 2011 grade 8 released mathematics items. Inggris: Cambridge International Examinations.

IEA.(2015). International surveys: PISA, TIMSS, PIRLS. Inggris: Cambridge International Examinations.

Indaryanti, Aisyah, N., Astuti, P., \& Winarni, S. (2017, 25-26 November). Development of the mathematics non-routine problems based on values for students of SMA. 
Paper presented at The First International Conference on Combinatorics, Graph Theory and Network Topology, Jember, Indonesia.

Indaryanti., Aisyah, N., \& Efriani, A. (2017, 21 August). Penanaman nilainilai matematika dengan pemodelan matematika. Paper presented at Seminar Nasional Matematika dan Pendidikan Matematika, Palembang, Indonesia.

Juanti, L., Santoso, B., \& Hiltrimartin, C. (2016). Peningkatan Kemampuan Pemecahan Masalah Siswa Menggunakan Model Pembelajaran Treffinger. Jurnal Tatsqif, 14(2), 198-217. doi: 10.20414/jtatsqif.v14i2.1072.

Kamus Pusat Bahasa. (2008). Kamus Bahasa Indonesia. Jakarta: Pusat Bahasa.

Kemendikbud. (2013). Kurikulum SMP/MTs. Jakarta: Ministry of National Education.

Kesumawati,N.(2009,5December).Peningkatan kemampuan pemecahan masalah matematis siswa SMP melalui pendekatan pendidikan matematika realistic. Paper presented at Seminar Nasional Matematika dan Pendidikan Matematika Jurusan Pendidikan Matematika FMIPA UNY, Yogyakarta, Indonesia. Retrieved from http://eprints.uny.ac.id/7049/ 1/P34\%20 Dra.\%20 Nila\%20Kesumawati.pdf.

Leung, F.K.S., Graf, K.D., \& Lopez-Real, F.J. (2006). Mathematics education in different cultural traditions a comparative study of East Asia and the west. United States of America: Springer Science + Business media, Inc.

Mairing, J.P. (2017). Kemampuan siswa sma dalam menyelesaikan masalah sistem persamaan linear tiga variabel. AKSIOMA. 6(1): 15-26. Retrieved from http://jurnal. untad.ac.id/ jurnal/index.php/AKSIOMA/ article/view/8365/6641.

Mujulifah, F., Sugiatno, \& Hamdani. (2015). Literasi matematis siswa dalam menyederhanakan ekspresi aljabar. JIPP. 4(1): 1-12. Retrieved from http://jurnal. untan.ac.id/in dex.php/jpdpb/article/ view/8766/8729.

NCTM. (1989). Curriculum and evaluation standards for school mathematics. Reston VA: The Council.

NCTM. (2000). Principles and standards for school mathematics. USA: The National Council of Teacher Mathematics inc.

Noer, S.H. (2009, 5 December). Peningkatan kemampuan berpikir kritis matematis siswa SMP melalui pembelajaran berbasis masalah. Paper resented at Seminar Nasional Matematika dan Pendidikan Matematika. Jurusan Pendidikan Matematika FMIPA UNY, Yogyakarta, Indonesia. Retrieved from http://eprints. uny.ac.id/7049/1/P34\%20 Dra.\%20 Nila\%20Kesumawati.pdf.

OECD. (2013). PISA 2012 assessment and analytical framework: mathematics, reading, science, problem solving, and financial literacy. Retrieved from https:// www.oecd. org/pisa.

OECD. (2016). Programme for international student assassement (PISA) result from PISA 2015. Retrieved from https://www. oecd.org/pisa.

Othman, N., Zakaria, E., \& Iksan, Z. (2014). Nilai dalam pengajaran matematika di institusi pengajian tinggi. e-jurnal penyelidikan dan inovasi. 1(2):56-68. Retrieved from http://rmc.kuis.edu.my/jpi/wpcontent/ uploads/2015/01/JPI 009.pdf.

Polya. G. (1973). How to solve it. Princenton, New Jersey: Princenton University Press. Retrieved from https://notendur.hi.is/hei2/ teaching/Polya_HowtoSolve It.pdf.

Resi, A. (2012). Nilai-nilai matematika (mathematical values) pada pembelajaran matematika di SMP negeri 15 Palembang. Skripsi. Palembang: Universitas Sriwijaya. 
Retnowati, E., Ayres, P., \& Sweller, J. (2018). Collaborative learning effects when students have complete or incomplete knowledge. Cognitive Psychology. 30(3):349-367. doi: 10.1002/acp.3444.

Retnowati, E., Fathoni, Y., \& Chen, O. (2018). Mathematics problem solving skill acquisition: learning by problem posing or by problem solving. Cakrawala Pendidikan. 37(1):1-10. doi: 10.21831/ cp.v37i1.18787.

Ruseffendi, H. (2006). Pengantar kepada membantu guru mengembangkan kompetensinya dalam pengajaran matematika untuk meningkatkan CBSA. Bandung: Tarsito.

Seah, W.T., \& Bishop, A.J. (2000, 24-28 April). Value in mathematics textbook: A view through two Australasian regions. Paper presented at the $81^{\text {st }}$. Annual Meeting of the American Educational Research Association, New Orlean, LA. Retrieved from http://www.education.monash.edu. au/projects/vamp/AERA_2000_VAMP. pdf.

Sternberg, R.J., \& Sternberg, K. (2012). Cognitive psychology (6 ed.). Belmont, CA: Wadsworth Cengage Learning.

Suandito, B. (2009). Pengembangan soal matematika non rutin di SMA xaverius 4 Palembang. Thesis. Palembang: Pascasarjana Unsri.

Sunarto, M.J.J., Budayasa, I.K., \& Juniati, D. (2017). Profil proses berpikir mahasiswa tipe kepribadian sensing dalam memecahkan masalah logika matematika. Cakrawala Pendidikan. 36(2), 299-308. doi: 10.21831/cp.v36i2.13119.

Tim Puspendik. (2016). Hasil TIMSS 2015 diagnosa hasil untuk perbaikan mutu dan peningkatan capaian. Jakarta: Puspendik Balitbang. Retrieved from http://puspendik. Kemdikbud.go.id/ seminar/upload/RahmawatiSeminar\%20 Hasil\%2TIMSS\%202015.pdf.
Utari, T., Arista, E.D.W., \& Fitri, A. (2016, 5 November). Masalah non rutin dalam buku ajar matematika untuk meningkatkan kemampuan berpikir kreatif. Paper presented at Seminar Nasional Matematika dan Pendidikan Matematika UNY 2016, Yogyakarta, Indonesia. P-34:484-493. Retrieved from http://seminar.uny.ac.id/ semnasmatematika/ sites/seminar.uny. ac.id.semnasmatematika/files/PM-79.pdf

Wardhani,S., Wiworo, Guntoro,S.T.,\& Sasongko, H.W. (2010). Pembelajaran kemampuan pemecahan masalah matematika di SMP. Yogyakarta: PPPPTK Matematika.

Widiyanti, P., Zubaidah., \& Yani, A. (2015). Analisis kesulitan siswa dalam menyelesaikan soal materi pecahan bentuk aljabar di kelas VIII SMP. JIPP. 4(9): 1-17. Retrieved from http://jurnal. untanac.id/index.php/jpdpb/article/ view/11534/10894.

Wijayanti, D. (2012). Analisis soal pemecahan masalah pada buku sekolah elektronik pelajaran matematika SD/MI. Majalah Ilmiah Sultan Agung Semarang. 50(126):1-12. Retrieved from http:// jurnal.unissula.ac.id/index.php/ majalahilmiahsultanagung/article view/57/51.

Yazgan, Y.(2016). Fourth graders and non-routine problems: are strategies decisive for success?. European Journal of Education Studies. 2(4): 100-119. Retrieved from https://oapub.org/edu/index.php/ejes/ article/view/242.

Yeo, \& Joseph, K.K. (2009). Secondary 2 students' difficulties in solving nonroutine problems. Journal of Mathematics Education. Retrieved from http://www. cimt.org.uk/ journal/yeo.pdf.

Zulkardi. (2005). Pendidikan matematika di Indonesia: beberapa permasalahan dan upaya penyelesaiannya. Paper presented at Pengukuhan sebagai Guru Besar Tetap pada FKIP UNSRI, Palembang. 